\title{
THE INCREASED NUMBER OF EPITHELIAL CELLS DETACHED FROM ORAL MUCOSA BECAUSE OF AMALGAM FILLINGS
}

\author{
(PENINGKATAN JUMLAH SEL EPITELIUM TERLEPAS PADA MUKOSA ORAL AKIBAT \\ TAMBALAN AMALGAM)
}

\author{
Ameta Primasari, Safriani Sitompul \\ Department of Oral Biology, Faculty of Dentistry, Universitas Sumatera Utara, \\ Medan, Sumatera Utara, Indonesia \\ Jl. Alumni No. 2 Kampus USU Medan 20155 \\ Corresponding email: ameta.primasari@usu.ac.id
}

\begin{abstract}
Amalgam is a filler material containing toxic mercury. One of the main risks comes from the mercury vapor released in the mouth. The presence of amalgams in the oral cavity changes the metabolism of epithelial cells in the oral mucosa. Exfoliative cytology is a fast and easy method because the examination is only performed on the surface of the oral mucosa, and epithelial cells can be released without anesthesia. The research method was an analytical descriptive with a cross-sectional design. Epithelial cells from oral mucosa were collected from 32 samples using the cytobrush method. The epithelial cells were collected on the closest buccal mucosa of the amalgam restoration. The number of epithelial cells in the oral mucosa was seen through micrographs from a microscope with 100x magnification. The data were analyzed using the Mann Whitney U test to determine the number of epithelial cells released. The Mann Whitney U test results showed that there was a significant difference in the number of oral mucosal epithelial cells obtained between subjects with amalgam and subjects without amalgam with $\mathrm{p}<0.05$. In addition, there was a difference in the features of oral mucosal epithelial cells between subjects with amalgam and subjects without amalgam. In conclusion, the number of epithelial cells obtained from amalgam users was higher than the subjects without restorations. The forms of epithelial cells which experience desquamation in the subjects with amalgam were more irregular than those of subjects without restorations.
\end{abstract}

Keywords : Amalgam, Oral mucosal epithelial cells, Exfoliative cytology

\begin{abstract}
Amalgam adalah bahan tambalan yang mengandung merkuri yang bersifat toksik. Salah satu risiko utama berasal dari uap merkuri yang dilepaskan di dalam mulut. Kehadiran amalgam dalam rongga mulut menyebabkan perubahan dalam metabolisme sel-sel epitel di mukosa mulut. Sitologi eksfoliatif adalah metode yang cepat dan mudah karena pemeriksaan hanya pada permukaan mukosa mulut dan sel epitel dapat dilepaskan tanpa anastesi. Metode penelitian ini adalah deskriptif analitik dengan desain cross sectional. Pengambilan sel epitel dari mukosa mulut dilakukan pada 32 sampel dengan menggunakan metode cytobrush. Pengambilan sel epitel dilakukan pada mukosa bukal yang terdekat dari restorasi amalgam. Jumlah sel epitel mukosa mulut terlihat melalui mikrograf dari mikroskop dengan pembesaran 100x. Data yang diperoleh dianalisis dengan menggunakan Mann Whitney U Test untuk mengetahui jumlah sel epitel yang terlepas. Hasil uji Mann Whitney U menunjukkan bahwa ada perbedaan yang signifikan pada jumlah sel epitel mukosa mulut yang diperoleh antara subjek dengan amalgam dengan subjek tanpa amalgam dengan nilai $p<0,05$. Selain itu, ada perbedaan dalam fitur sel epitel mukosa mulut pengguna amalgam dengan tanpa pengguna amalgam. Berdasarkan penelitian ini, dapat disimpulkan bahwa jumlah sel epitel yang diperoleh pada pengguna amalgam lebih tinggi dibandingkan dengan subjek tanpa restorasi. Bentuk sel-sel epitel yang mengalami deskuamasi pengguna amalgam lebih tidak teratur dibandingkan sel sel epitel deskuamasi yang tanpa restorasi.
\end{abstract}

Kata Kunci: Amalgam, Sel oral mucosal epithelial cells, Sitologi exfoliative 


\section{INTRODUCTION}

Amalgam is one of the materials which are most often used for restorative treatment, especially in the posterior area. There are several reasons why amalgam becomes a popular restoration material such as relatively inexpensive cost, easy to use, and durable. $^{1,2}$ Many controversies, however, occurs among medical personnel regarding the safety of amalgam, especially the mercury content which has long-term adverse effects on the patient's body. The toxicity of mercury becomes one of the reasons that many dentists stop using amalgam. ${ }^{2}$

Mercury is the only liquid type of metal. Mercury is toxic, so it is dangerous if it enters the human body. ${ }^{3}$ The source of mercury exposure in dental practice comes when handling amalgam. ${ }^{4}$ One of the main risks of amalgam is the release of mercury vapour which occurs during its use in the mouth. ${ }^{5}$ Mercury vapour can be released from amalgam fillings during all steps of restoration such as trituration, condensation, setting, polishing, and releasing amalgam fillings from the teeth. Chewing and drinking hot drinks can also release mercury from amal gam fillings.,

The classic signs of chronic mercury exposure are gingivitis, alveolar bone loss, tooth loss, ulcers in the oral cavity, and excessive saliva. As the outermost layer, oral mucosa protects oral tissue from the external environment. Oral mucosa will adapt to the epithelium and connective tissue to resist mechanical force and abrasion caused by normal activities such as mastication. Besides, the epithetlial lining of the mouth will act as a protection against the population of microorganisms which is left in the oral cavity that can cause infection if it enters the tissue. ${ }^{7,8}$

There have been many studies on the dangers of amalgam and toxicity of mercury. ${ }^{8-10}$ However, there is no previous research about the presence of epithelial cells in the oral mucosa due to amalgam fillings. The authors were, therefore, interested in conducting research on the description of epithelial cells in the oral mucosa of amalgam filling users. Amalgam material was chosen in this study because many people have used amalgam as the filling material to date.

The method used in this study was the cytobrush method. This method was chosen based on the method which is most often used in the oral cavity. The cells were collected on the buccal mucosa area near the amalgam fillings. The present study aimed to determine the increase in the number of epi- thelial cells in the oral mucosa of amalgam fillings users.

\section{MATERIALS AND METHODS}

The research design was a cross-sectional study with a consecutive sampling method. The subjects were 32 people who fulfilled the inclusion criteria (subjects aged $18-25$ years, using amalgam fillings, and willing to participate in the study) and exclusion criteria (using orthodontic devices, taking routine medication, smokers, betel consumers, alcohol drinkers, women in menstruation, pregnancy or breastfeeding condition, have a history of systemic diseases, and infections/ lesions in the oral cavity such as caries, gingivitis, and periodontitis).

The research sampling of dental students in the University of Sumatera Utara was conducted at the Oral Biology Laboratory in the Faculty of Dentistry, University of Sumatera Utara. The research has received an approval letter from the Ethics Committee No: 126/TGL/KEPK FK USU-RSUP HAM/2017. Firstly, the subjects were asked for the willingness to participate in the study and received an explanation sheet and informed consent. Secondly, the samples were collected using the cytobrush method on the oral mucosa with one-time examination followed by staining the samples at the Anatomical Pathology Laboratory in the Faculty of Medicine, University of Sumatera Utara by using Hematoxylin-eosin staining. Finally, the samples were observed at the Microbiology Laboratoryin the Faculty of Mathematics and Natural Sciences by using micrographs from a microscope.

\section{RESULTS}

The photographs of epithelial cells were printed using an IP 2770. The number of epithelial cells was then calculated from each part using a counter and added up. This calculation was done three times to avoid bias in the calculation.

One criterion of cells calculated was epithelial cells which had a cell nucleus. If these cells accumulated, the cells can be counted by counting the number of cell nucleus which appeared. In contrast, the exclusion criteria for the cell calculation were cells that coincided with the photo line.

Data on the number of epithelial cells were tabulated and analyzed statistically with a significance level $(\mathrm{p}=$ $0.05)$. The test used in this research was the Mann Whitney test to compare the number of epithelial cells 
obtained from users and non-users of amalgam fillings.

Table 1. Data on the characteristics of amalgam subjects based on the length of the use of restoration

\begin{tabular}{|c|c|c|}
\hline Duration (Year) & $\mathrm{N}$ & $(\%)$ \\
\hline $1-2$ & 3 & 18.75 \\
$3-4$ & 5 & 31.25 \\
$\geq 5$ & 8 & 50 \\
Total & 1 & 100 \\
\hline
\end{tabular}

Table 1 shows that most of the subjects with amalgam fillings have used the restoration for more than 5 years.

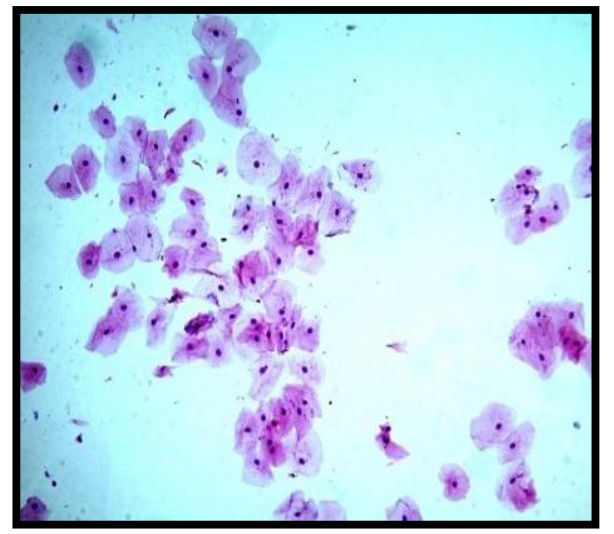

Figure 1. Epithelial cells in the users of amalgam fillings with $10 \times 10$ microscope magnification.

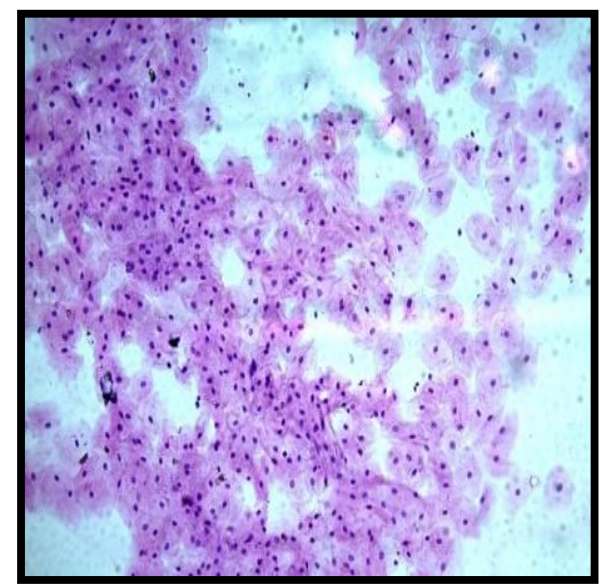

Figure 2. Epithelial cells in thenon-users of amalgam fillings with $10 \times 10$ microscope magnification.

Table 2. The number of epithelial cells based on the Mann Whitney test results.

\begin{tabular}{|l|l|l|l|l|}
\hline Group & $\mathrm{N}$ & Mean & SD & Sig \\
\hline Amalgam & 16 & 773.12 & 431.92 & \multirow{2}{*}{0.000} \\
\cline { 1 - 4 } $\begin{array}{c}\text { Without } \\
\text { amalgam }\end{array}$ & 16 & 336.12 & 115.78 & \\
\hline
\end{tabular}

The Mann Whitney test analysis results in Table 2 show a significant difference with $\mathrm{p}<0.05$ between subjects with amalgam fillings and subjects without amalgam fillings in terms of the number of epithelial cells obtained.

Normal epithelial cells are characterized by a regular round cytoplasm, and there is a round nucleus in it. Based on this study, however, epithelial cells from the oral mucosa in the subjects with amalgam fillings underwent irregular changes in the morphological form than epithelial cells in subjects without fillings. In this study, various epithelium cell forms were found. For example, there was enlarged cytoplasm with a round nucleus, flatter cytoplasm with a flat nucleus, and cytoplasm with a hexagonal shape.

\section{DISCUSSION}

The length of use of fillings forthe subjects who had amalgam fillings (Table 1) shows that most of the subjects have used amalgam fillings for more than 5 years with a total of 8 subjects $(50 \%)$. The longer its use in the oral cavity will affect the function and biocompatibility of the fillings. It will then affect the oral mucosal state because the mercury content in amalgam is considered toxic if it enters the human body. One of the main risks of amalgam is the release of mercury vapour from amalgam which occurs when it is used in the mouth. Mercury vapor can be released from amalgam fillings during all steps of restoration such as trituration, condensation, setting, chewing, and drinking hot drinks. ${ }^{8,9,10}$

The results of the Mann Whitney $U$ test analysis (Table 2) show that there was a significant difference in the number of epithelial cells between the group who had amalgam fillings and the group who did not have amalgam fillings with a significant $\mathrm{p}$-value $=$ 0.000 . The group with amalgam fillings had more epithelial cells $(773.12 \pm 431.92)$ than the group without amalgam fillings (336.12 \pm 115.78$)$. Thus, this study is in accordance with the hypothesis that the number of cells in the subjects with amalgam fillings was greater than that of the subjects without amalgam fillings. Epithelial cells have a function to protect organisms or living things from damage caused by microbes, both physical and chemical materials. The presence of amalgam fillings in the oral cavity as a foreign object which has toxic chemical content of mercury triggers the increase of mucosal epithelial cells. ${ }^{11}$ Primasari in 2013 conducted a study comparing the cytobrush and scraping method on exfoliative oral mucosal cytology. The study found that the number of epithelial cells using the cytobrush method was an average of $212 \pm$ 36.345. The samples were collected from normal oral 
mucosa with good $\mathrm{OH}$ and no lesions. Women who were menstruating were excluded. ${ }^{12}$

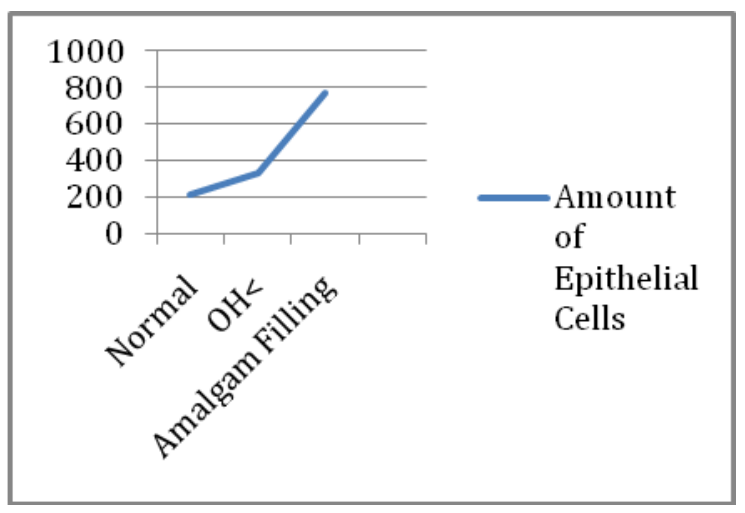

Figure 3. Increased number of epithelial cells which occurred in the normal mucosa in subjects with and without amalgam fillings.

Kasacka et al. ${ }^{12}$ conducted a study in 2010 about Salivary cells in the users of amalgam fillings and composite resins. The study found that the number of oral epithelial cells in the amalgam users from the saliva was higher than that of the control group without fillings. Furthermore, there were morphological changes in epithelial cells in the saliva of subjects with amalgam fillings including larger cell size, irregular shape, different intensity of cytoplasm staining, and comparison changes to the nucleus into the cytoplasm. This can be caused by changes in oral epithelial cell metabolism and hyperkeratosis associated with chemical, thermal, and physical irritation. ${ }^{13}$ In this study, the forms of epithelial cell in the subjects who had amalgam fillings were more iregular than the subjects who did not have amalgam fillings.

Based on the statement above, it can be concluded that amalgam fillings can affect the oral mucosal state, especially the condition of epithelial cells. Moreover, there was an increase in the number of epithelial cells of subjects without fillings compared with the normal mucosal state and the users of amalgam fillings.

\section{REFERENCES}

1. Irawan B. Material restorasi direk kedokteran gigi saat ini. JDI 2004; 11(1): 24-8.

2. Stephen M. Mercury from dental amalgam: exposure and risk assessment. Compedium 2013; 34(2): 138-46.

3. Nonong YH. Kontroversi penggunaan amalgam pada perawatan gigi anak. In: Fakultas Kedokteran Gigi Universitas Padjadjaran, ed. Proceedings of $53^{\text {th }}$ Dies Forum Scientific Meeting. Bandung, 2012.

4. Tavane PN, Mehta D, Sajjan G. Mercury vapor release from amalgam restoration: study in vitro. WJD 2010; 1(2): 79-84.

5. ADA. Direct and indirect restorative materials. J Am Dent Assoc 2003; 134(4): 465-7.

6. Uçar Y, Brantley WA. Biocompatibility of dental amalgam. Int J Dent 2011; 2011: 1-5.

7. Puspitawati R. Strukturma kroskopik dan microskopik jaringan lunak mulut. JDI 2003; 10(2): 462-6.

8. Berniyanti T, Hariyanti N. Side effects of mercury in dental amalgam. Airlangga Dent J 2008; 41(1): 30-4.

9. Horsted-Bindsley P, Magos L, Holmstrup P, Arenholt-Bindsley D. Tambalan amalgam berbahaya untuk kesehatan? Alih Bahasa. Sumawinata N. Jakarta: EGC, 1998: 28-84.

10. Irnamanda DH, Elza A, Budiawan. Toksisitas amalgam dan kaitannyadengan polimorfisme gen CPOX4 pada jalurbiosintesis heme. J PDGI 2013; 62(2): 48-55

11. Primasari A, Desmiana D. Perbandingan metode cytobrush dengan scraping pada eksfoliatif sitologi mukosa normal rongga mulut. In: $1^{\text {st }}$ Lustrum School of Dental Medicine Universitas Brawijaya. Proceeding DTEAM $3^{\text {rd }}$ Dental Technoloy Exhibition and Meeting. Malang, 2014.

12. Kasacka I, Lapinska J. Salivary cells in patient with dental amalgam and composite resin material restorations - a morphological investigation. Polish $\mathrm{J}$ of Environ 2010; 19(6): 1223-7 